\title{
Pengembangan Perangkat Pembelajaran Kontekstual dengan Pendekatan Guided Inquiry Materi Tumbuhan Berbiji Pada Siswa SMK Farmasi Nusaputera
}

\author{
Bunga Ihda Norra \\ Prodi Pendidikan Biologi, Fakultas Sains dan Teknologi, UIN Walisongo Semarang \\ Email : bungaihda@walisongo.ac.id
}

\begin{abstract}
Abstrak
Penelitian ini bertujuan untuk mengetahui model perangkat pembelajaran biologi yang selama ini digunakan di SMK Farmasi Nusaputera, mengembangkat perangkat pembelajaran biologi pendekatan kontekstual metode guided inquiry pada materi tumbuhan berbiji dan untuk mengetahui efektivitas perangkat pembelajaran biologi dengan pendekatan kontekstual metode guided-inquiry pada materi tumbuhan berbiji dalam upaya meningkatkan aktivitas, motivasi dan hasil belajar siswa. Jenis penelitian merupakan penelitian Research and Development. Tahapan penelitian terdiri dari riset dan pengembangan. Riset dilakukan untuk mengetahui keadaan awal dari tempat penelitian. Pengembangan dilakukan untuk merencanakan, menyususn, menguji coba dan memvalidasi perangkat pembelajaran, dalam tahap ini dilakukan validasi perangkat dan uji coba perangkat. Uji coba dilakukan untuk mengukur keefektifan dan kepraktisan perangkat. Keefektifan ditentukan berdasarkan aktivitas, motivasi dan hasil belajar siswa sedangkan kepraktisan ditentukan berdasarkan respon guru dan siswa. Dari hasil penelitian dan pengembangan diperoleh perangkat pembelajaran yang valid, efektif dan praktis. Perangkat dinyatakan valid sebab perangkat berada dalam kriteria sangat baik. Perangkat dinyatakan efektif sebab perangkat dapat meningkatkan aktivitas, motivasi dan hasil belajar siswa, dapat dilihat melalui perbandingan dengan kelompok eksperimen dan perangkat dinyatakan praktis sebab > 75\% respon guru dan siswa menyatakan baik. Perangkat pembelajaran pendekatan kontekstual metode guided inquiry dapat diterapkan pada materi pembelajaran yang lain misalnya materi ekosistem dan tumbuhan paku. Perangkat dapat digunakan pada materi dan tempat lain dengan penyesuaian terhadap sumber belajar dan kondisi lingkungan di sekitar siswa.
\end{abstract}

Kata kunci : Contextual Teaching Learning, metode guided inquiry, aktivitas, motivasi dan hasil belajar siswa

\section{Pendahuluan}

Pembelajaran Biologi dikembangkan untuk melatih kemampuan berpikir analitis, induktif. Pembelajaran Biologi yang hanya bersifat hafalan dan memecahkan soal-soal tertulis dianggap tidak efektif untuk mengembangkan kemampuan berpikir siswa (dalam penelitian ini hasil belajar siswa). Untuk menghadapi permasalahan tersebut siswa dalam proses belajarnya harus dilatih berpikir dengan dihadapkan dengan permasalahan yang biasa siswa hadapi sehari-hari, salah satunya dengan pembelajaran kontekstual (Setiawan, 2008).

Salah satu upaya yang dapat dilakukan untuk mengatasi masalah tersebut adalah dengan melakukan proses belajar mengajar yang berpusat pada siswa, yaitu dengan meningkatkan peran aktif siswa dalam proses belajar mengajar. Salah satu pendekatan yang sesuai untuk meningkatkan peran aktif siswa adalah pendekatan kontekstual. Pendekatan kontekstual akan mengajak siswa 
untuk mengkaitkan materi yang dipelajari dengan kehidupan sehari-harinya. Pendekatan kontekstual akan memberikan kesempatan kepada siswa untuk melakukan serangkaian proses pembelajaran, sehingga siswa memperoleh pengalaman belajar dan dapat membangun pemahamannya sendiri terhadap materi pembelajaran. Pembelajaran akan lebih menyenangkan dengan menggunakan pendekatan kontekstual, karena siswa belajar dalam suasana senang mengikuti pembelajaran. Mereka dituntut aktif untuk memperoleh pengalaman belajarnya.

Pembelajaran merupakan sebuah sistem mengajar, didasarkan pada pikiran bahwa makna muncul dari hubungan antara isi dan konteksnya. Konteks memberikan pada isi. Semakin banyak ketertarikan yang ditemukan siswa dalam suatu konteks yang luas, semakin bermaknalah isinya bagi mereka. Jadi, sebagian besar tugas seorang guru adalah menyediakan konteks. Semakin mampu para siswa mengaitkan pelajaran-pelajaran akademis mereka dengan konteks, semakin banyak makna yang akan mereka dapatkan dari pelajaran tersebut. Kemampuan mengerti makna dari pengetahuan dan keterampilan akan menuntun pada penguasaan pengetahuan dan keterampilan (Johnson, 2007).

Berdasarkan hasil observasi di SMK Farmasi Nusaputera pada semester ganjil (hasil wawancara dengan guru biologi). Pembelajaran Biologi dilaksanakan dengan model pembelajaran yang cenderung memisahkan konsep yang dipelajari dengan realitas kehidupan sehari-hari, sehingga semakin menjauhkan hubungan konsep-konsep biologi dengan alam sekitar dan kehidupan siswa. Kondisi ini dapat menimbulkan persepsi yang keliru, dan melepaskan relevansi ilmu biologi dengan realitas kehidupan siswa. Pembelajaran juga bersifat verbalistik yang kurang memanfaatkan potensi lingkungan sekitar sebagai sumber belajar yang paling dekat dengan diri siswa.
Tingkat pemahaman materi tumbuhan berbiji siswa yang masih rendah yaitu 44,12. Hal ini diduga karena sistem pembelajaran masih monoton dan tidak bervariasi. Contextual Teaching Learning (CTL) atau dikenal juga dengan pendekatan kontekstual. Pendekatan kontekstual merupakan konsep belajar yang membantu guru mengkaitkan materi yang diajarkan dengan lingkungan sekitar siswa dan mendorong siswa untuk menghubungkan antara pengetahuan yang mereka dapat dengan penerapannya dalam kehidupan sehari-hari di masyarakat.

\section{Metode Penelitian}

\section{Jenis penelitian}

Jenis penelitian ini adalah pengembangan (research and development). Pengembangan yang dilakukan adalah pada perangkat pembelajaran kontekstual metode guided-inquiry pada materi tumbuhan berbiji di kelas XI SMK Farmasi Nusa Putera.

\section{Subjek Penelitian}

Penelitian ini dilaksanakan di kelas XI D sebagai kelas eksperimen dan di kelas XI B sebagai kelas kontrol.

\section{Variabel Penelitian}

Variabel penelitian yang akan diteliti antara lain: Validitas, Efektivitas dan Keterterapan produk (perangkat pembelajaran).

\section{Desain Penelitian}

Pengembangan perangkat pembelajaran bertujuan untuk menghasilkan perangkat pembelajaran yang baik, untuk pengembangan perangkat pembelajaran dalam penelitian ini menggunakan model Thiagarajan Sammel dan Sammel (Trianto, 2007).

\section{Data dan Cara Pengambilan Data}

Data yang digunakan dalam penelitian ini meliputi data kualitatif dan data kuantitatif. Data 
kualitatif yaitu data respons siswa terhadap pembelajaran kontekstual, dan kevalidan perangkat pembelajaran. Sedangkan data kuantitatif berupa data hasil belajar dan aktivitas belajar. Data berupa hasil pelaksanaan pembelajaran yaitu aktivitas belajar, motivasi belajar, persepsi siswa yang didapat melalui pengembangan perangkat pembelajaran biologi dengan pembelajaran kontekstual.

\section{Analisis Data}

Analisis data yang dilakukan bertujuan untuk mengetahui tingkat kevalidan dan keterlaksanaan pembelajaran. Analisis yang dilakukan meliputi indikator validitas, efektivitas dan keterterapan.

Indikator dari penelitian ini antara lain:

a. Validitas

Perangkat pembelajaran dinyatakan valid jika skor dari validator ahli berada dalam rentang baik dan sangat baik.

\section{b. Efektivitas}

Perangkat pembelajaran dinyatakan efektif jika rerata skor hasil belajar kelompok eksperimen lebih tinggi dibandingkan kelompok kontrol, tingkat aktivitas siswa termasuk aktif atau sangat aktif dan tingkat motivasi siswa baik atau sangat baik.

c. Keterterapan

Perangkat pembelajaran dinyatakan dapat diterapkan jika skor respons guru dan siwa $\geq 75 \%$ atau memberikan respons positif terhadap perangkat pembelajaran.

\section{Hasil dan Pembahasan}

Hasil belajar berupa tes kemampuan materi tumbuhan berbiji. Hmelo-silver (2007) menyatakan bahwa terdapat bukti dari penelitian eksperimental yang menunjukkan pembelajaran metode inkuiri menghasilkan peningkatan hasil belajar yang signifikan dibandingkan pembelajaran konvensional/ceramah,

Hasil penelitian pada kelas eksperimen menunjukkan rata-rata klasikal kelas eksperimen lebih tinggi dibandingkan kelas kontrol. Pembelajaran bersifat teacher centered yang mengakibatkan kelas kontrol memiliki rata-rata lebih rendah. Joyful learning pada kelas eksperimen meningkatkan aktivitas siswa, meningkatnya aktivitas disertai dengan meningkatnya motivasi siswa. Peningkatan motivasi dan keinginan siswa dapat meningkatkan hasil belajar siswa. Sehingga rerata dari kelas eksperimen meningkat jika dibandingkan pada tes awal yang dilakukan sebelum dilakukan pembelajaran dengan pendekatan kontekstual. Pada post test setelah pembelajaran dilakukan didapatkan rerata kelas eksperimen 70,9 dimana ada 4 orang siswa yang tidak KKM (65). Jadi ada 89\% siswa yang telah mencapai KKM. Hal ini berarti rata-rata siswa kelas XI D (eksperimen) telah mampu mencapai KKM yang telah ditetapkan yaitu $\geq 65$. Dengan demikian kelas XI D telah mampu mencapai ketuntasan belajar. Pada kelas kontrol rata - rata klasikal siswa adalah 63 dimana sebanyak 20 siswa tidak KKM. Jadi ada 44\% siswa yang mencapai KKM.

Hasil belajar siswa kelas eksperimen dan kontrol kemudian dianalisis menggunakan uji $\mathrm{t}$. Derajat kebebasan untuk tabel distribusi $\mathrm{t}$ adalah $\left(\mathrm{n}_{1}+\mathrm{n}_{2}-2\right)$ dengan peluang $(1-1 / 2 \alpha)$ dengan taraf signifikan $\alpha=5 \%$. Setelah data diolah, maka dapat ditentukan Ho ditolak atau diterima. Ho diterima

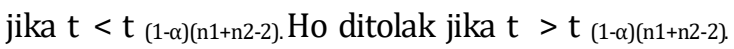
Perangkat dikatakan efektif apabila rata-rata kelompok eksperimen lebih tinggi dari kelompok kontrol. Berdasarkan uji t diketahui $\mathrm{t}$ berada pada daerah penolakan Ho, maka dapat disumpulkan bahwa kelompok eksperimen lebih baik daripada kelompok kontrol, karena $\mathrm{t}>\mathrm{t}_{(0.95)(70)}$ yaitu $3.796>$ 1.67, sehingga Ho ditolak, jadi rata - rata kelas eksperimen lebih baik dibandingkan kelas kontrol.

Hasil evaluasi belajar pada kelas eksperimen menunjukkan bahwa siswa mampu mengikuti dan memahami makna pembelajaran secara kontekstual dalam materi tumbuhan berbiji. Perangkat pembelajaran dapat dikategorikan efektif 


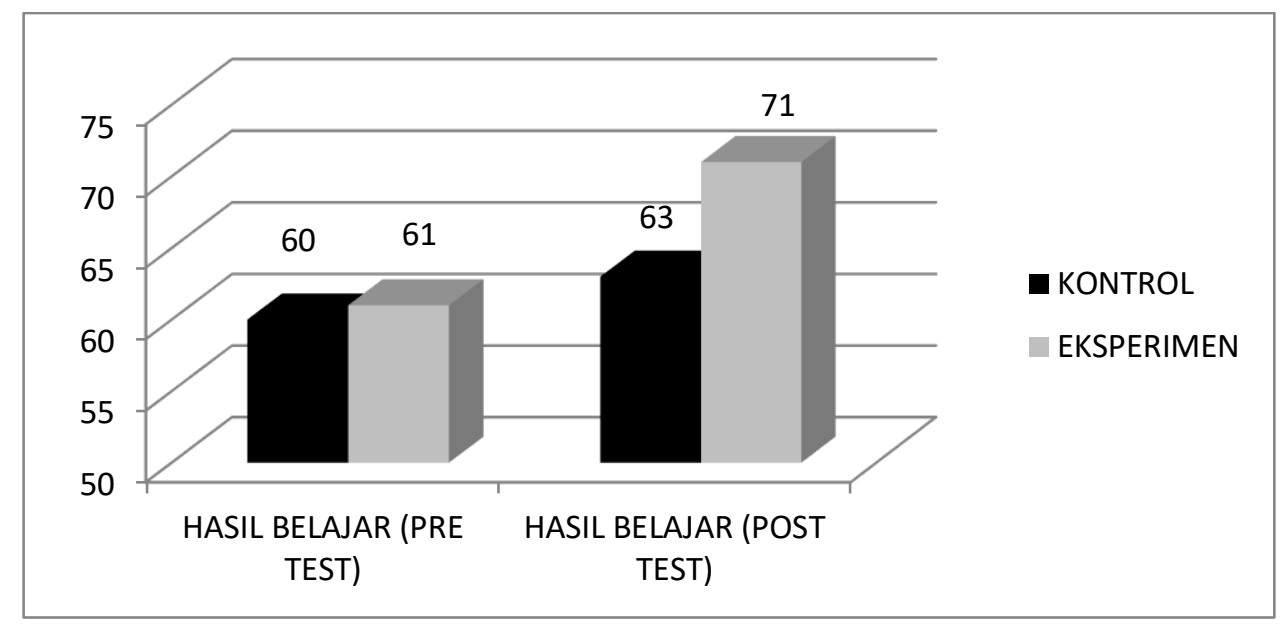

Gambar 1. Tingkat persentase hasil belajar siswa kelas kontrol dan eksperimen

Berdasarkan uraian di atas dapat disimpulkan bahwa peningkatan pada aktivitas siswa dapat meningkatkan motivasi dan hasil belajar siswa. Pada kelas eksperimen peningkatan dari tes awal menuju tes akhir terdapat peningkatan cukup tinggi (10 poin), sedangkan pada kelas kontrol meskipun terjadi peningkatan namun tidak banyak (3 poin). Hal ini membuktikan meningkatnya aktivitas dapat meningkatkan motivasi serta hasil belajar siswa.
Hasil rekapitulasi respons siswa dapat terlihat bahwa pada kelas eksperimen umumnya siswa tertarik dengan model pembelajaran kontekstual dilihat dari angka persentase berkisar antara 77\% hingga 83\%. Berdasarkan kriteria pada indikator maka kisaran angka tersebut masuk dalam kriteria tertarik. Berdasar respons siswa, siswa lebih tertarik dengan model pembelajaran kontekstual dibandingkan pembelajaran secara konvensional (ceramah).

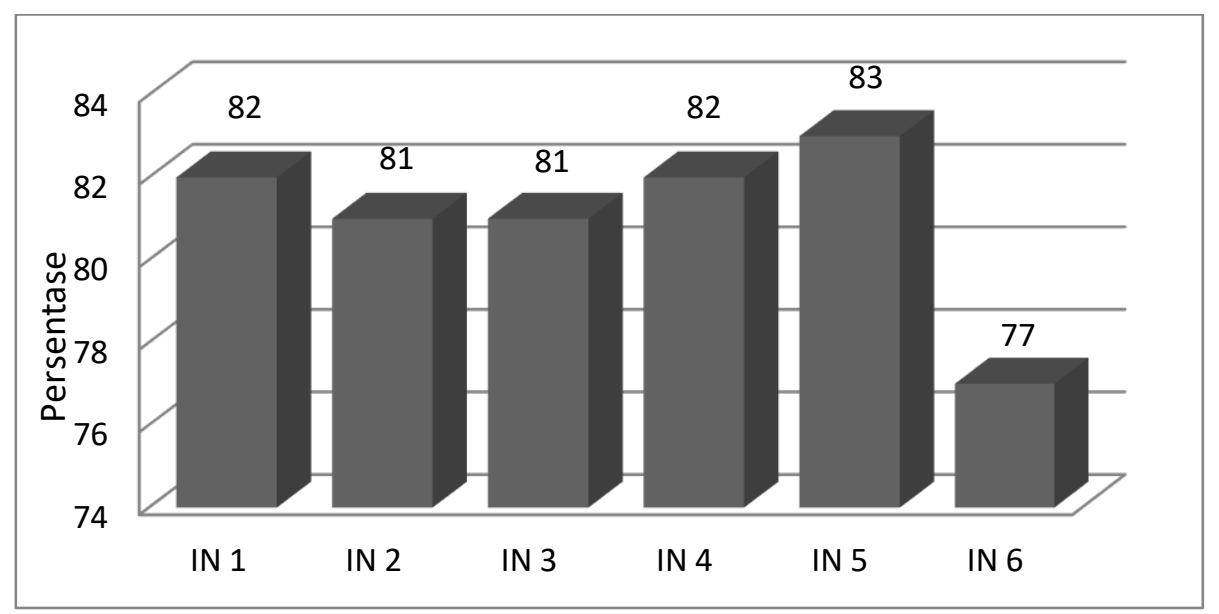

Gambar 2. Tingkat persentase data respons siswa

Keterangan :

IN 1: Keingintahuan siswa

IN 2: Ketertarikan siswa

IN 3: Variasi metode pembelajaran
IN 4: Pemahaman siswa

IN 5: Aktivitas siswa

IN 6: Kesesuaian modul 
Siswa senang dengan pembelajaran Biologi secara kontekstual karena siswa memperoleh hal baru yang sebelumnya tidak siswa ketahui. Dengan mencari sendiri siwa akan mengerti konsep konsep dasar dari materi yang diajarkan, selain hal tersebut siswa dapat mentransfer informasi antar teman satu kelompok maupun antar kelompok di dalam kelas . Respons siswa termasuk dalam kategori baik, respons ini memberikan gambaran bahwa siswa merasa senang, nyaman dan termotivasi oleh pembelajaran yang ditetapkan. Siswa juga mendapatkan banyak kesempatan dalam mengeluarkan pendapat, dengan adanya kegiatan diskusi. Siswa dapat terlibat aktif dalam kegiatan diskusi sehingga memunculkan ide-ide baru, mempertahankan ide mereka dengan konsep yang sudah mereka peroleh sebelumnya.

Respons guru berada pada kisaran 75\% hingga 90\%, hal ini berarti guru merespons baik terhadap perangkat pembelajaran model kontekstual yang telah digunakan. Menurut pengamat/guru mitra pembelajaran dengan model kontekstual baik dan pelaksanannya dapat diterapkan pada materi lain selain tumbuhan berbiji.

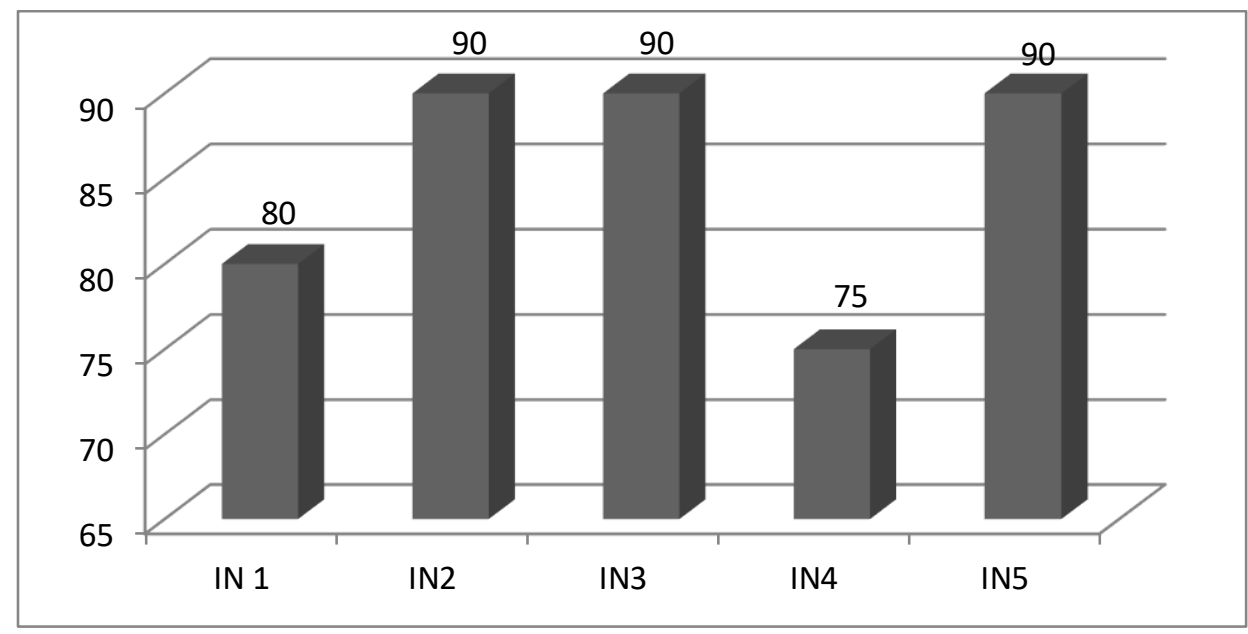

Gambar 3. Diagram data respons guru

Keterangan :

IN 1: Kemudahan penggunaan perangkat

IN 2: Keefisienan penggunaan waktu

IN 3: Ketertarikan siswa terhadap pembelajaran

IN 4: Kesesuaian dengan perkembangan siswa

IN 5: Pemahaman siswa terhadap pembelajaran

Perangkat pembelajaran model kontekstual ini dapat membuat siswa berperan aktif dalam kegiatan pembelajaran di kelas, selain itu model kontekstual ini dapat digunakan untuk meningkatkan motivasi dan hasil belajar siswa, sehingga guru mitra tertarik untuk menerapkan pembelajaran kontekstual pada konsep pembelajaran yang lain. Respons tertinggi (90\%)

terdapat pada indikator 2 dan 3 mengenai keefisienan penggunaan waktu dan ketertarikan siswa terhadap pembelajaran. Ketertarikan siswa bertambah dikarenakan adanya pembelajaran yang berbeda dibandingkan dengan pembelajaran pada umumnya, sehingga timbul ketertarikan pada diri siswa. 
Hasil angket terhadap pembelajaran kontekstual menunjukkan adanya respons positif dari guru, dilihat dari ketertarikan guru mitra untuk mengimplementasikan pembelajaran kontekstual pada konsep pembelajaran yang lainnya, selain itu siswa dapat mencapai hasil belajar yang maksimal. Maka perangkat pembelajaran model kontekstual ini dikatakan dapat diterapkan karena guru memberikan respons positif $\geq 75 \%$.

Temuan-temuan pada penelitian ini antara lain: dampak positif dalam pembelajaran kontekstual ini adalah meningkatnya aktivitas bertanya antar siswa dan guru, maupun antar siswa dengan siswa, timbulnya antusiasme pada siswa untuk mengikuti pembelajaran. Siswa terlihat aktif melakukan kegiatan pembelajaran di kelas, pengetahuan siswa dapat bertahan lebih lama, karena adanya pembelajaran yang bersifat nyata.

\section{Kesimpulan}

Berdasarkan hasil dan pembahasan penelitian, dapat disimpulkan bahwa perangkat pembelajaran biologi dengan pendekatan kontekstual metode guided-inquiry yang dikembangkan dapat dikatakan valid dan efektif yang dapat dilihat dari nilai validator yang berada dalam kriteria sangat baik dan perangkat dikatakan efektif karena dapat meningkatkan aktivitas, motivasi dan hasil belajar siswa, dilihat dari perbandingan aktivitas, motivasi dan hasil belajar antara kelas eksperimen dan kelas kontrol.

\section{Saran}

Untuk kepentingan penelitian, maka penulis menyarankan perlu dilakukan penelitian lebih lanjut mengenai perangkat pembelajaran biologi dengan metode contextual guided-inquiry yang dapat mengukur kemampuan berpikir bebas dan kreatif siswa, serta dapat diimplementasikan pada materi biologi selain materi tumbuhan berbiji, misalnya ekosistem dan klasifikasi makhluk hidup. Perangkat ini dapat digunakan pada materi lain dengan penyesuaian terhadap materi, alat dan bahan. Perangkat ini dapat digunakan di sekolah lain, terutama sekolah yang memiliki green house atau kebun alam di sekitarnya.

\section{Daftar Pustaka}

Agustina, N. 2009. Pengembangan Model Pembelajaran Kontekstual Berbasis Hand On Project Untuk Meningkatkan Hasil Belajar dan Keterampilan Proses Sains. Tesis Program Studi Pendidikan IPA. Pps Unnes

Arikunto, S. 2009. Dasar-Dasar Evaluasi Pendidikan (Edisi Revisi). Bumi Aksara. Jakarta.

Berns, R., dan Erickson, P. 2009. Contextualized Teaching and Learning: $A$ Faculty Primer. The Chancellor's Office of The California Comunity College. San Fransisco.

Gulo, W. 2008. Strategi Belajar Mengajar. Grasindo. Jakarta.

Hakim, L. 2008. Pendekatan Contextual Teaching And Learning Dengan Memanfaatkan Lingkungan Sebagai Media Pembelajaran Entomologi. Jurnal Pendidikan Serambi, 5(2): $94-98$.

Hamalik, 0. 2008. Proses Relajar Mengajar. Bumi Aksara. Jakarta.

Hmelo-Silver, C.E., R.G. Duncan, dan C.A Chinn. 2007. Scaffolding and Achievement in ProblemBase and Inquiry Learning: A Responsse to Kirschner, Sweller and Clark (2006). Educational Psychologist, 42(2): 99-107.

Ibrahim, M. 2010. Pembelajaran inkuiri. UNESA. Surabaya.

Indriyati. 2010. Representasi Konsep Biologi Kontekstual. Tesis. Program Studi Pendidikan IPA. Pps Unnes.

Johnson, E. 2014. Contextual Teaching and Learning. MLC. Bandung.

Kalchik, S, Dan Oertle, K. 2010. The Theory and Application Of Contextualized Teaching and Learning In Relation To Programs Of Study And Career Pathway. Transition Highlight. 2: 1-6.

Kurniawati, Yati. 2010. Pengembangan Bahan Ajar Optika SMP Berbasis Inkuiri dan Bervisi SETS. 
Palmer, D.H. 2009. Student Interest Generated During an Inquiry Skills Lesson. Journal of Research in Science Teaching. 46 (2): 147165.

Rivet, A., dan Krajick, J. 2008. Contextualizing Instruction. Journal of Research In Science Teaching, 45(1): $79-100$.

Setiawan, I. 2008. Penerapan Pengajaran Kontekstual Berbasis Masalah Untuk Meningkatkan Hasil Belajar Biologi. Jurnal Penelitian dan Pengembangan Pendidikan Undiksha, 2(1): 42 - 59.

Siswanty, F. 2008. Pengembangan Model Pembelajaran Kontekstual Dengan Pendekatan Jelajah Alam Sekitar. Tesis Program Studi Pendidikan IPA. Pps Unnes.

Sugiyono. 2010. Metode Penelitian pendidikan Pendekatan Kuantitatif, Kualitatif dan R\& D. Alfabeta. Bandung.
Sukahar. 2009. Pengembangan Perangkat Pembelajaran Matematika CTL. Pps Unnes. Semarang.

Suyanto. 2007. Pemanfaatan Kegiatan Laboratorium Berwawasan Inkuiri Terbimbing Untuk Meningkatkan Kompetensi Berkomunikasi Ilmiah. Pps Unnes. Semarang.

Trianto. 2007. Model Pembelajaran Terpadu dalam Teori dan Praktik. Prestasi Pustaka. Jakarta.

Tuan, Hsio-Lin. et al. 2005. Investigating The Effectiveness of Inquiry Instruction on the Motivation of Different Learning Styles Students. International Journal of Science and Mathematics Education, 3(4): 541-566.

Westera, W. Reframing Contextual Learning: Anticipating the Virtual Extensions of Context in Educational Technology and Society. International Forum of Educational Technology and Society, 2: 1-17. 